\title{
Detection of gastrointestinal parasites in small-scale poultry layer farms in Leyte, Philippines
}

\author{
Rochelle Haidee D. Ybañez ${ }^{1,2}$, Kurt Jimwell G. Resuelo ${ }^{1}$, Ara Patrice M. Kintanar ${ }^{1}$ and Adrian P. Ybañez ${ }^{1,3}$
}

1. Department of Biology and Environmental Science, College of Science, University of the Philippines Cebu, Gorordo Avenue, Lahug, Cebu City, Philippines; 2. Unit for Host Defense, National Research Center for Protozoan Diseases, Obihiro University of Agriculture and Veterinary Medicine, Obihiro City, Hokkaido, Japan; 3. Department of Clinical Veterinary Science, College of Veterinary Medicine at Barili Campus, Cebu Technological University, Barili, Cebu, Philippines. Corresponding author: Adrian P. Ybañez, e-mail: dr.adrianpybanez@gmail.com

Co-authors: RHDY: rochelledybanez@gmail.com, KJGR: kgresuelo@up.edu.ph, APMK: amkintanar@up.edu.ph Received: 10-06-2018, Accepted: 09-10-2018, Published online: 19-11-2018

doi: 10.14202/vetworld.2018.1587-1591 How to cite this article: Ybañez RHD, Resuelo KJG, Kintanar APM, Ybañez AP (2018) Detection of gastrointestinal parasites in small-scale poultry layer farms in Leyte, Philippines, Veterinary World, 11(11): 1587-1591.

\begin{abstract}
Background: Gastrointestinal (GIT) parasites can affect poultry productivity by compromising its health. It is well studied in other countries, but the documented reports in the Philippines have been limited.
\end{abstract}

Aim: The aim of the present study was to evaluate the presence of GIT parasites in selected small-scale poultry layer farms in Leyte, Philippines.

Materials and Methods: A total of 243 stool samples from eight small-scale poultry layer farms in Leyte, Philippines, were examined for GIT parasites using floatation and sedimentation technique. Profile parameters were also obtained. Fecal samples were collected and analyzed using floatation and sedimentation techniques. Statistical significance between GIT parasite positivity and profile parameters was determined using Chi-square test.

Results: GIT parasites were detected in $92.2 \%$ of the samples $(24.7 \%$ with single infection, $42.0 \%$ with $2-3$ parasites, and $25.5 \%$ with three or more parasites). The common parasites detected were Ascaridia spp. (41.2\%), Heterakis spp. (59.3\%), Capillaria spp. (10.7\%), Eimeria spp. (43.2\%), and Strongyloides spp. (74.1\%). Some profile parameters, including farm location, years in business, number of workers, nearby water system, the practice of fecal cleaning, and presence of other animals, were found to be significantly associated with GIT positivity.

Conclusion: GIT parasites were detected in the poultry of small-scale layer farms in selected areas in Leyte, Philippines. This finding calls for the importance of routine GIT parasite monitoring and the implied need for regular deworming or dewormer rotation in the area.

Keywords: gastrointestinal parasites, layer chickens, Leyte, Philippines, small-scale farms.

\section{Introduction}

Poultry layer production is presently among the fastest growing industries in the Philippines. Chicken meat and eggs have also become one of the most popular food commodities being vital sources of protein in the human diet [1]. Compared to other livestock, the production cost of poultry raising per unit is low, and the return on investment is faster and higher [2]. At present, most chickens and eggs sold in the market are produced by local, small-scale poultry layer farms [3].

Despite the growth of the Philippine poultry industry, the economics of poultry farming is still hampered by frequent outbreaks of diseases. Of these diseases, parasitic infections by gastrointestinal (GIT) parasites cause more considerable damage and massive

Copyright: Ybañez, et al. Open Access. This article is distributed under the terms of the Creative Commons Attribution 4.0 International License (http://creativecommons.org/licenses/ by/4.0/), which permits unrestricted use, distribution, and reproduction in any medium, provided you give appropriate credit to the original author(s) and the source, provide a link to the Creative Commons license, and indicate if changes were made. The Creative Commons Public Domain Dedication waiver (http:// creativecommons.org/publicdomain/zero/1.0/) applies to the data made available in this article, unless otherwise stated. economic losses due to malnutrition, decreased feed conversion, weight loss, lowered egg production, and death in juvenile birds [4]. The common GIT parasites that infect poultry include helminths, cestodes, nematodes, and protozoans, with mixed infections being widespread [5]. These GIT parasites have morphological and physiological features adapted to live longer in their hosts [6]. Risk factors that contribute to the spread of these parasites into the layer chickens include poultry transports, neighborhood infection, unhygienic practices of farms, and the introduction of infected foreign birds [7].

There has been a significant decrease in the prevalence of most of the parasitic diseases in commercial poultry production systems through refined housing, hygiene, and administration [8]. However, parasitic infections are still significant problems in egg-producing small-scale layer farms. The Philippine Statistics Authority [9] reported an increase in the inventory of layer and native chicken in the Philippines compared to the previous year's inventory. This increase has also increased egg production. The growth of the Philippine poultry industry denotes a continuing 
need to improve the prevention of chicken parasitic infections for a continuous distribution of quality and safe products. Furthermore, there is a constant need to assess the status of the layer chicken production and the risk factors affecting it.

To the best of the authors' knowledge, there are no published reports yet regarding the presence of GIT parasites in layer chickens in Leyte, Philippines. The information on the presence of these parasites will be integral in understanding their epidemiology and the necessary preventive measures that can be done. Hence, this study aimed to detect GIT parasites in small-scale poultry layer farms in selected areas in Leyte, Philippines.

\section{Materials and Methods}

\section{Ethical approval}

The procedures performed in this study were guided by the principles of animal welfare, Animal Welfare Act of the Philippines (RA 8485) and Administrative Order No. 45 of the Bureau of the Animal Industry of the Philippines.

\section{Informed consent}

The farm owners were interviewed but were limited to farm data and not about the farm owners. Only letters of request were sent. In the Philippine laws, informed consent to people are required by ethics if the interview covers that of the personal information of the respondents.

\section{Selection and profiling of small-scale layer farms and animals}

This descriptive, analytical study was conducted in eight small-scale layer farms in Leyte, Philippines, which were purposively selected. The study was conducted from April to June 2016. In the Philippines, there is not much difference in the season in the weather conditions. Hence, the season is not seen as a factor. Routine preventive deworming is performed based on age of the bird. Before the actual sampling, letters were sent to each farm requesting approval to conduct the study. The farm owners or workers on duty were then interviewed to obtain the farm and animal profiles. The profile parameters include farm location, farming type and housing elements, deworming program, and management system.

\section{Fecal sample collection}

In as much as we would want to get samples from each bird, the birds are not caged individually in the layer houses, and thus, it may be difficult to ascertain which bird defecated. Thus, stool samples were preferred. Furthermore, in actual practice here in the Philippines, we only do random sampling to diagnose a farm and treat the entire layer house or farm. We do not treat individual animals, especially in worm infestation. Fecal samples were collected from freshly excreted feces or on-ground feces. Approximately $10 \mathrm{~g}$ of feces were obtained per sample from different pens (regardless of the number of animals per pen) and were transferred into properly labeled containers. Labeled containers have information on sample number, production phase, date of collection, pen number, and number of heads (per pen). Immediately after collection, $10 \%$ formaldehyde was added to the samples and was stored at $4{ }^{\circ} \mathrm{C}$ until analysis.

\section{Fecal analysis}

Approximately $1 \mathrm{~g}$ of each of the preserved fecal samples was processed using sugar solution and distilled water for floatation [10] and sedimentation methods [11], respectively. Examination of parasite eggs was done under a light microscope. Structural and morphometric criteria were utilized during the identification of the eggs [12]. The analysis was limited to the use of fecal samples, and necropsy was not performed to recover worms.

\section{Data collection, processing, and analyses}

Obtained profile and fecalysis results were manually encoded in Microsoft Excel. Descriptive statistics were employed. Statistical significance was determined using Chi-square test. The positivity rate (PR) was computed using the following formula:

$$
\text { PR of parasite }=\frac{\begin{array}{l}
\text { number of stool pools found } \\
\text { positive with the parasite }
\end{array}}{\begin{array}{l}
\text { total number of stool } \\
\text { pools analyzed }
\end{array}} \times 100
$$

\section{Results and Discussion}

Profile of selected small-scale layer farms in Leyte

The layer population in the farms ranged from 500 to 4000 heads. Most adapted $\square$-4birds per cage and all had slatted floors. Only one farm had free-roaming chickens in the area. Most had two buildings, which had been operating for 2-10 years. The farms had 1-6 workers and were mostly using pellet type of feeds. The ma $\square$ orityhad no nearby water system with no closed perimeters. Cleaning of feces was usually done every $\square$ - $\square$ days (Table-1). These profile parameters were reported to have a significant association with productivity and GIT parasite presence $[\square, 1 \square-15]$.

It was noted during fecal collection that all farms reportedly dewormed their flock every $\square-6$ months. Parasites may acquire resistance to therapeutic drugs made to combat their spread in layer chickens, thereby increasing the incidence of infection [15]. Despite regular deworming, GIT parasites were still detected in all eight farms.

\section{GIT parasites detected in layer chickens in Leyte}

A total of $24 \square$ samples were collected from the eight participating poultry layer farms in Leyte. Fecalysis results revealed that GIT parasites were detected in $\square 2.2 \%$ of the samples (24. $\square \%$ with single infection, $42.0 \%$ with $2-\square$ parasites, and $25.5 \%$ with three or more parasites). The GIT parasites detected were Ascaridia spp. (41.2\%), Heterakis spp. (5 $\square . \square \%)$, 


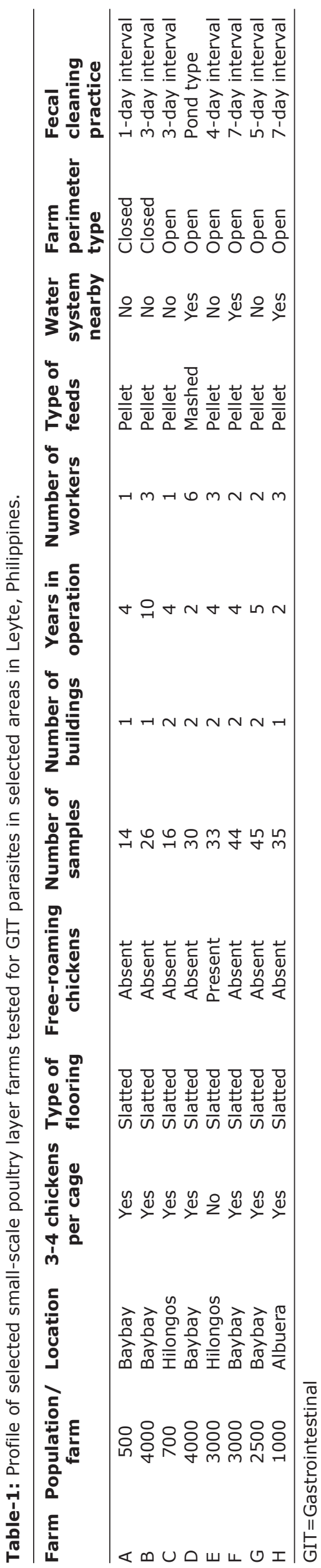

Capillaria spp. (10.7\%), Eimeria spp. (43.2\%), and Strongyloides spp. (74.1\%) (Table-2 and Figure-1).

Strongyloides spp. eggs had the highest PR among the parasites detected (Table-2). It is a soil-transmitted, parasitic, and zoonotic nematode that invades the ceca. Strongyloides spp. has been one of the highly isolated nematode parasites in chickens [16].

The second most detected, Heterakis spp., has been isolated and identified in various prevalence studies on GIT parasites of chickens [17]. Histopathological findings discovered that Heterakis infestation in the GIT caused severe damage to the cecal architecture, necrosis of lamina propria, and the overall destruction of intestinal glands. Infected cecum exhibited muscular alterations and tearing [18].

Coccidia, such as Eimeria spp., are one of the most important protozoan parasites of poultry, both in terms of distribution, frequency, and economic losses [19]. They are passed through a chicken's droppings and attach itself to the intestinal lining. Outward signs of coccidiosis include droopiness, loss of appetite, blood or mucus in the feces, diarrhea, dehydration, and even death $[20,21]$. Many farms are vulnerable to the transmission of this parasite through the transportation of personnel and equipment. New farms alike have a high probability of acquiring this parasite within a few weeks after poultry introduction [19].

Ascaridia spp., on the other hand, are commonly reported parasitic and zoonotic nematodes of the chicken that lives in the small intestine. Several studies have found it to be the most prevalent and pathogenic nematode species of the chicken [22]. The high frequency of this parasite is likely due to its direct life cycle. Ingestion of water and food contaminated by infective eggs leads to the development of the egg into its larval stage when reaching the small intestine [23]. Parasite infestation is characterized by gross lesions in the small intestine, hemorrhage, intestinal wall thickening, the presence of nodules, and necrotizing enteritis [24].

\section{Statistical analysis of profile parameters and GIT parasite positivity}

Selected profile parameters including farm location, years in business, number of workers, proximity to a water system, frequency of fecal cleaning, and presence of other animals were found significantly associated $(\mathrm{p}<0.05)$ with GIT parasite positivity (Table-3). Other farm profiles including age, flooring, caging density and presence of free-roaming chickens, type of feeds, farm system, the presence of insects, and dead/sick chickens showed no significant association to the frequency of detected parasites.

The farm location influencing the presence of parasites reveals that there might be different management practices or parasite biodiversity in the area. However, farm location may not be a significant factor if the characteristics of the farms are similar [25]. On the other hand, the number of years the farm is in business was found to be another significant factor. The birds in the farms may be older since the prevalence 
Available at www.veterinaryworld.org/Vol.11/November-2018/10.pdf

Table-2: Detection rate (\%) of GIT parasites in the selected farms in Leyte, Philippines ( $n=243$ stool pools)

\begin{tabular}{|c|c|c|c|c|c|c|c|c|c|}
\hline \multirow[t]{2}{*}{ Parasite } & \multicolumn{8}{|c|}{ Farm } & \multirow{2}{*}{$\begin{array}{c}\text { Total } \\
(n=243)\end{array}$} \\
\hline & $A(n=14)$ & B $(n=26)$ & $C(n=16)$ & $D(n=30)$ & $E(n=33)$ & $F(n=44)$ & $G(n=45)$ & $H(n=35)$ & \\
\hline Ascaridia spp. & 14.3 & 84.6 & 81.3 & 56.7 & 27.3 & 56.8 & 0.0 & 34.3 & 41.2 \\
\hline Heterakis spp. & 57.1 & 88.5 & 75.0 & 70.0 & 75.8 & 63.6 & 33.3 & 34.3 & 59.3 \\
\hline Capillaria spp. & 0.0 & 7.7 & 0.0 & 3.3 & 12.1 & 20.5 & 20.0 & 2.9 & 10.7 \\
\hline Eimeria spp. & 35.7 & 76.9 & 75.0 & 56.7 & 24.2 & 61.4 & 13.3 & 28.6 & 43.2 \\
\hline Strongyloides spp. & 35.7 & 76.9 & 62.5 & 96.7 & 66.7 & 95.5 & 64.4 & 65.7 & 74.1 \\
\hline
\end{tabular}

GIT=Gastrointestinal

Table-3: Statistical analysis results between profile and GIT parasite positivity.

\begin{tabular}{lc}
\hline Parameter & p-value \\
\hline Farm location & $0.00 *^{*} *$ \\
Flooring & 1.000 \\
Caging & 0.747 \\
Free roaming & 0.747 \\
Number of buildings & 0.334 \\
Years in business & $0.021^{*}$ \\
Number of workers & $0.042^{*}$ \\
Type of feeds & 0.086 \\
Water system nearby & $0.012^{*}$ \\
Farm system & 0.376 \\
Frequency of fecal cleaning & $0.001^{*}$ \\
Presence of other animals & $0.007 * *$ \\
Presence of insects & 0.376 \\
Presence of dead/sick chickens & 0.334 \\
\hline
\end{tabular}

*Significant, **Highly significant, GIT=Gastrointestinal

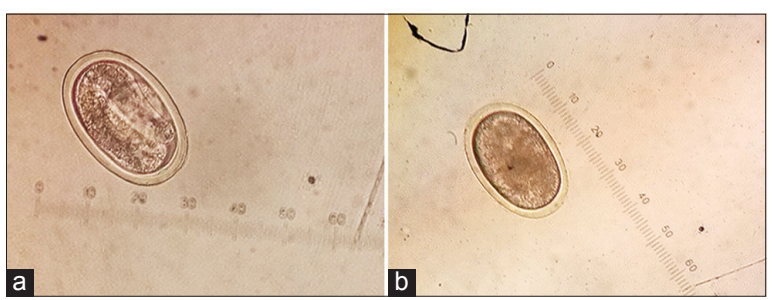

Figure-1: Strongyloides (a) and Ascaridia (b) spp. eggs detected in layer chickens in Leyte, Philippines.

of parasitic infections can accumulate with increasing age of generations [26]. Furthermore, more years in business could entail more generations of birds that share and accumulate similar parasitic loads.

The number of workers on the farm may also affect GIT positivity. The more workers in the farm, the more people are there to take care of the cleanliness of the farm and care for the birds and the basic needs [27]. Similarly, maintenance of flock density, chicken segregation, and control of environmental factors, such as water and food, are all accomplished through the workers [28].

The proximity to a water source, as well as the presence of other types of animals, such as pigs and dogs, may also influence the existence of parasites [29]. Other animals on the farm can be sources of contamination, especially when problems of farm management and poultry handing are rampant [30].

\section{Conclusion}

GIT parasites were detected in all farms at a high level $(92.2 \%)$. The most common parasites detected were Ascaridia spp. (41.2\%), Heterakis spp. (59.3\%), Capillaria spp. (10.7\%), Eimeria spp. (43.2\%), and Strongyloides spp. (74.1\%). Some profile parameters, including farm location, years in business, number of workers, nearby water system, the practice of fecal cleaning, and presence of other animals, were found to be significantly associated with GIT positivity. This study is the first survey on GIT parasites in smallscale poultry layer farms in selected areas in Leyte, Philippines.

\section{Authors' Contributions}

RHDY, KJGR, and APMK contributed equally to the study. APY conceptualized the study and analyzed and corrected the manuscript. All authors have read and approved the final manuscript.

\section{Acknowledgments}

The authors would like to thank the poultry farm owners in Leyte, Philippines, who allowed the conduct of the research and the Commission on Higher Education of the Philippines (CHED), for partially supporting the project through the DARE TO GRANT (Discovery-Applied Research and Extension for Trans/ Inter-disciplinary Opportunities) which was approved through CHED en bank Resolution no. 852-2017.

\section{Competing Interests}

The authors declare that they have no competing interests.

\section{References}

1. Farrell, D. (2013) The Role of Poultry in Human Nutrition. The Role of Poultry in Human Nutrition, Poultry Development Review, Food and Agriculture Organization of the United Nations. Available from: http://www.fao. org/docrep/013/al709e/al709e00.pdf. Last accessed on 30-01-2018.

2. Ojo, S.O. (2003) Productivity and technical efficiency of poultry egg production in Nigeria. Int. J. Poult. Sci., 2(6): 459-464.

3. Sonaiya, E.B. and Swan, S.E. (2007) Small-Scale Poultry Production: Technical Guide. Daya Publishing House, Delhi.

4. Poulsen, J., Permin, A., Hindsbo, O., Yelifari, L., Nansen, P. and Bloch, P. (2000) Prevalence and distribution of gastrointestinal helminths and haemoparasites in young scavenging chickens in upper eastern region of Ghana, West Africa. Prev. Vet. Med., 45(3-4): 237-245.

5. Luka, S.A. and Ndams, I.S. (2007) Short communication report: Gastrointestinal parasites of domestic chicken Gallus-gallus domesticus linnaeus 1758 in Samaru, Zaria Nigeria. Sci. World J., 2(1): 27-29. 
6. Belete, A., Addis, M. and Ayele, M. (2016) Review on major gastrointestinal parasites that affect chickens. J. Biol. Agric. Healthc., 6(11): 11-21.

7. Thomas, M., Bouma, A., Ekker, H., Fonken, A., Stegeman, J. and Nielen, M. (2005) Risk factors for the introduction of high pathogenicity avian influenza virus into poultry farms during the epidemic in the Netherlands in 2003. Prev. Vet. Med., 69(1-2): 1-11.

8. Permin, A. and Hansen, J.W. (1998) Epidemiology, Diagnosis, and Control of Poultry Parasites. Food and Agriculture Organization of the United Nations, Rome.

9. Philippines Statistics Authority. (2016) Chicken Industry Performance Report. Available from: https://www.psa. gov.ph/sites/default/files/CHICKEN\%20Industry\%20 Performance\%20Report\%20-\%20Jan\%20-\%20Dec\%20 2015 0.pdf. Last accessed on 30-01-2018.

10. Dryden, M.W., Payne, P.A., Ridley, R. and Smith, V. (2005) Comparison of common fecal flotation techniques for the recovery of parasite eggs and oocysts. Vet. Ther., 6(1): 15-28.

11. Gibbons, L.M., Jacobs, D.E., Fox, M.T. and Hansen, J. (2005) The RVC/FAO Guide to Veterinary Diagnostic Parasitology: Faecal Examination of Farm Animals for Helminth Parasites. Available from: http://www.rvc.ac.uk/ review/Parasitology/Index/Index. Htm. Last accessed on 31-01-2018.

12. Beugnet, F., Polack, B. and Dang, H. (2008) Atlas of Coproscopy. Kalianxis, Italy.

13. Babatunde, S.M., Mohammed, B.R., Simon, M.K. and Agbede, R.I.S. (2016) Coccidial infection in free-range and intensively managed chickens in Gwagwalada area council, Abuja-Nigeria, Sub-Saharan Africa. Alex. J. Vet. Sci., 51(2): 183-188.

14. Gorrín, A., Colas, C., Meireles, R., \& Pérez, R. (2018) Effect of the sanitary situation of the poultry house on the larval stages of endoparasites in the intermediate hosts and on the productive performance. Revista de Investigaciones Veterinarias del Perú (RIVEP), 29(3): 908-915.

15. Aiello, S.E. (2016) Merck Veterinary Manual. $11^{\text {th }}$ ed. Merck and Company, Incorporated, Kenilworth, New Jersey.

16. de Silva, G.S., Romera, D.M., da Silva Conhalato, G., Soares, V.E. and Meireles, M.V. (2018) Helminth infections in chickens (Gallus domesticus) raised in different production systems in Brazil. Vet. Parasitol. Reg. Stud. Rep., 12(1): 55-60.

17. 1och, A., Kuchling, S., Hess, M. and Hess, C. (2018) Influence of alternative husbandry systems on postmortem findings and prevalence of important bacteria and parasites in layers monitored from end of rearing until slaughter. Vet. Rec., 182(12): 350-350.

18. Butt, Z., Shaikh, A.A., Memon, S.A. and Mal, B. (2014)
Prevalence of cestode parasites in the intestine of local chicken (Gallus domesticus) from Hyderabad, Sindh, Pakistan. J. Entomol. Zool. Stud., 2(6): 301-303.

19. McDougald, L.R. (1997) Other protozoan diseases of the intestinal tract. In: Diseases of Poultry. $10^{\text {th }}$ ed. Iowa State University Press, Ames, Iowa.

20. Allen, P.C. and Fetterer, R.H. (2002) Recent advances in biology and immunobiology of Eimeria species and in diagnosis and control of infection with these coccidian parasites of poultry. Clin. Microbiol. Rev., 15(1): 58-65.

21. Györke, A., Pop, L. and Cozma, V. (2013) Prevalence and distribution of Eimeria species in broiler chicken farms of different capacities. Parasite, 20(1): 50.

22. Kumar, S., Garg, R., Ram, H., Maurya, P.S. and Banerjee, P.S. (2013) Gastrointestinal parasitic infections in chickens of upper Gangetic plains of India with special reference to poultry coccidiosis. J. Parasit. Dis., 39(1): 22-26.

23. Permin, A., Magwisha, H., Kassuku, A., Nansen, P., Bisgaard, M., Frandsen, F. and Gibbons, L. (1997) A cross-sectional study of helminths in rural scavenging poultry in Tanzania in relation to season and climate. J. Helminthol., 71(3): 233-240.

24. Tay, L.K., Emikpe, B.O., Ockling, S., Folitse, R.D. and Jarikre, T.A. (2017) Point prevalence and pathology associated with gastrointestinal parasites in local chickens and guinea fowls in Kumasi, Ghana. Niger. J. Parasitol., 38(1): 91-97.

25. Rufai, M.A. and Jato, A.O. (2017) Assessing the prevalence of gastrointestinal tract parasites of poultry and their environmental risk factors in poultry in Iwo, Osun state Nigeria. Ife J. Sci., 19(1): 7-13.

26. Burlet, P., Deplazes, P. and Hegglin, D. (2011) Age, season and spatio-temporal factors affecting the prevalence of Echinococcus multilocularis and Taenia taeniaeformis in Arvicola terrestris. Parasit. Vectors, 4(1): 6.

27. Clauer, P. (2010) Raising Fowl in Urban Areas. Penn State College of Agricultural Sciences Research and Extension, Pennsylvania State University. Available from: https:// www.extension.psu.edu/raising-fowl-in-urban-areas. Last accessed on 30-01-2018.

28. Adetayo, K.A., Ademiluyi, I.O. and Itebu, J.O. (2013) Challenges of small poultry farms in layer production in Ibadan Oyo state Nigeria. Glob. J. Sci. Front. Res. Agric. Vet. Sci., 13(2): 4-11.

29. Mwale, M. and Masika, P.J. (2009) Ethno-veterinary control of parasites, management and role of village chickens in rural households of Centane district in the Eastern Cape, South Africa. Trop. Anim. Health Prod., 41(8): 1685-1693.

30. Damerow, G. (2015) The Chicken Health Handbook: A Complete Guide to Maximizing Flock Health and Dealing with Disease. $2^{\text {nd }}$ ed. Storey Publishing, USA.

\section{$* * * * * * * *$}

